\title{
Pengaruh Kecerdasan Intelektual, Kecerdasan Emosional, dan Kecerdasan Spiritual Pemilik Pada Kinerja Usaha Mikro Kecil Menengah
}

\author{
Rio Surya Wijaya Theda ${ }^{1}$ \\ Made Sukartha ${ }^{2}$
}

${ }^{1}$ Fakultas Ekonomi dan Bisnis Universitas Udayana (Unud), Bali, Indonesia
email: rio_suryawijaya@yahoo.com/Telp: +6285 237434043
${ }^{2}$ Fakultas Ekonomi dan Bisnis Universitas Udayana (Unud), Bali, Indonesia

\begin{abstract}
ABSTRAK
Pembangunan nasional suatu bangsa mencakup didalamnya pembangunan ekonomi dan Usaha Mikro Kecil Menengah (UMKM). Kinerja UMKM perlu diteliti karena kontribusi sektor UMKM terhadap Produk Domestik Bruto (PDB) meningkat dari 57,84\% menjadi $60,34 \%$ dalam 5 tahun terakhir. Penelitian ini bertujuan untuk mengetahui pengaruh kecerdasan intelektual, kecerdasan emosional, dan kecerdasan spiritual pemilik pada kinerja Usaha Mikro Kecil Menengah.Obyek penelitian adalah kinerja UMKM di Kota Denpasar. Teknik penentuan sampel yang digunakan dalam penelitian ini adalah Probably sampling digunakan dengan menggunakan teknik random sederhana. Terdapat 100 UMKM sebagai sampel dengan pernyataan kuesioner yang jumlah 71 pernyataan. Berdasarkan hasil analisis penelitian diperoleh kecerdasan intelektual memiliki pengaruh positif pada Kinerja UMKM, Kecerdasan Emosional memiliki pengaruh positif pada Kinerja UMKM, dan Kecerdasan Spiritual memiliki pengaruh positif pada Kinerja UMKM.
\end{abstract}

Kata kunci: Kecerdasan Intelektual, Kecerdasan Emosional, dan Kecerdasan Spiritual.

\begin{abstract}
National development of a nation includes economic development and Micro, Small and Medium Enterprises (MSMEs). MSME performance needs to be examined because the contribution of the MSME sector to the Gross Domestic Product (GDP) has increased from $57.84 \%$ to $60.34 \%$ in the last 5 years. This study aims to determine the effect of intellectual intelligence, emotional intelligence, and spiritual intelligence of the owner on the performance of Micro, Small and Medium Enterprises. Research subjects are the performance of UMKM in Denpasar City. The sample determination technique used in this study is Probably sampling used using a simple random technique. There are 100 MSMEs as samples with a questionnaire statement totaling 71 statements. Based on the results of the analysis of research obtained intellectual intelligence has a positive influence on the performance of MSMEs, Emotional Intelligence has a positive influence on the performance of SMEs, and Spiritual Intelligence has a positive influence on the performance of SMEs.
\end{abstract}

Keywords: Intellectual Intelligence, Emotional Intelligence, and Spiritual Intelligence.

\section{PENDAHULUAN}

Pembangunan ekonomi diperlukan peran serta lembaga keuangan untuk membiayainya. Sebagai lembaga keuangan, bank memiliki banyak kegiatan yang menunjang pergerakkan UMKM, yang bertujuan untuk menghimpun dana dari 
Rio Surya Wijaya Theda dan Made Sukartha. Pengaruh...

masyarakat dan menyalurkannya lagi kepada masyarakat berupa pinjaman, kredit dan sejenisnya.

Pemerintah memilih sektor UMKM sebagai sektor yang perlu mendapatkan perhatian karena menurut beberapa ahli kekuatan perekonomian Indonesia terletak pada UMKM. Kinerja UMKM perlu diteliti karena kontribusi sektor UMKM terhadap Produk Domestik Bruto (PDB) meningkat dari 57,84\% menjadi 60,34\% dalam 5 tahun terakhir. Dari sisi serapan tenaga kerja, UMKM mampu menyerap tenaga kerja hingga 57,9 juta di berbagai daerah di Indonesia. Setiap tahunnya jumlah UMKM di Indonesia juga terus meningkat (www.cnnindonesia.com 2016).

Kota Denpasar merupakan ibukota dari provinsi Bali dan tentunya sebagai sebuah ibu kota, Denpasar juga menjadi pusat pusat pemerintahan, pusat perdagangan, pusat pendidikan, pusat industri, pusat ekonomi dan pusat pariwisata yang terdiri dari 4 kecamatan, yaitu Denpasar Barat, Denpasar Timur, Denpasar Selatan, Denpasar Utara.

Banyaknya pelaku UMKM di Kota Denpasar merupakan asset tersendiri yang bisa memperkuat pondasi perekonomian daerah serta dapat menjadi sumber pendapatan bagi pemerintah daerah, selain itu peran serta UMKM dapat mewujudkan pertumbuhan ekonomi, pemerataan, peningkatan pendapatan masyarakat, menciptakan lapangan pekerjaan, dan pencegah kemiskinan di Kota Denpasar (http://ukmdiskop.denpasarkota.go.id).

Sejalan dengan nilai masukan diatas, maka pemberdayaan UMKM Kota Denpasar perlu diselenggarakan secara menyeluruh, optimal dan kesenambungan 
melalui pemberian kesempatan berusaha, dukungan, perlindungan, dan pengembangan usaha seluas-luasnya, sehingga mampu meningkatkan kedudukan, peran, dan potensi UMKM.

Jumlah UMKM di Kota Denpasar selalu mengalami peningkatan dari tahun 2011 sampai 2017. Dimana pada tahun 2011 jumlah UMKM di Kota Denpasar terdapat 11.515 UMKM (https://bankdata.denpasarkota.go.id), sedangkan pada tahun 2017 terdapat $31.826 \quad$ UMKM (http://ukmdenpasarkota.info/ukmdiskop.denpasarkota.go.id).

Kinerja dapat dipengaruhi oleh dua faktor, yaitu faktor internal dan faktor eksternal. Faktor eksternal merupakan faktor yang berasal dari lingkungan pekerjaan seperti budaya organisasi, sikap dan tindakan rekan kerja juga struktur organisasi UMKM tersebut. Sementara faktor internal meliputi kecerdasan yang dimilikinya, terdapat beberapa kecerdasan pada diri manusia, di antaranya: kecerdasan intelektual, kecerdasan emosional, dan kecerdasan spiritual. Apabila ketiga kecerdasan tersebut dapat berfungsi secara efektif maka akan menampilkan hasil kerja yang menonjol (Choiriah, 2013).

Adapun faktor internal yang meliputi kecerdasan intelektual, kecerdasan emosional, dan kecerdasan spiritual sangat berpengaruh bagi seseorang untuk melakukan sesuatu dengan maksimal, agar mencapai suatu keberhasilan yang diinginkan (Trihandini, 2005). Maka dari itu, saya lebih tertarik meneliti faktor internal dari kinerja tersebut.

Kecerdasan intelektual atau yang biasa disebut dengan IQ merupakan kecerdasan yang dibangun oleh otak kiri. Menurut Goleman (2006), kecerdasan 
Rio Surya Wijaya Theda dan Made Sukartha. Pengaruh...

intelektual mampu menyumbang 20 persen kesuksesan dan 80 persen berasal dari kekuatan-kekuatan lain termasuk dari kecerdasan emosional.Robbins dan Judge (2008:57) mengatakan kecerdasan intelektual adalah kemampuan yang dibutuhkan untuk melakukan berbagai aktivitas mental berpikir, menalar, dan memecahkan masalah.

Kecerdasan emosional menjadikan seseorang mampu mengelola emosi dan mengenali perasaan diri sendiri dan orang lain. Menurut Goleman (1999) menggunakan istilah kecerdasan emosional untuk menggambarkan sejumlah keterampilan yang berhubungan dengan keakuratan penilaian tentang emosi diri sendiri dan orang lain, serta kemampuan mengelola perasaan untuk memotivasi, merencanakan, dan meraih tujuan kehidupan. Menurut Boyatzis (1999) dan Chermiss (1998), bahwa karyawan yang memiliki kecerdasan emosional yang baik akan menghasilkan kinerja yang lebih baik, yang dapat dilihat dari kualitas dan kuantitas yang diberikan karyawan.

Kecerdasan spiritual merupakan kemampuan mengerti dan memberikan makna spiritual atas kehidupannya, dengan memiliki kecerdasan spiritual yang baik, maka akan lebih mampu menghadapi berbagai persoalan yang akan di alami. Maka dari itu, kecerdasan spiritual merupakan landasan yang diperlukan untuk memfungsikan kecerdasan intelektual dan kecerdasan emosional secara efektif. Secara singkat kecerdasan spiritual mampu mengintegrasikan dua kemampuan lain yang sebelumnya telah disebutkan, yaitu kecerdasan intelektual dan kecerdasan emosional (Floretta, 2014). Mitroff dan Denton (1999), dalam penelitiannya membedakan kecerdasan spiritual dengan religiusitas di dalam 
lingkungan kerja. Religiusitas lebih ditujukan pada hubungannya dengan Tuhan sedangkan kecerdasan spiritual lebih terfokus pada suatu hubungan yang dalam dan terikat antara manusia dengan sekitarnya secara luas. Pekerja yang dapat memberi makna pada hidup dan membawa spiritualitas ke dalam lingkungan kerja akan membuat pekerja tersebut menjadi orang yang lebih baik, sehingga kinerja yang dihasilkan juga lebih baik dibanding pekerja yang bekerja tanpa memiliki kecerdasan spiritual (Hoffman, 2002:133). Biberman dan Whittey (1997) mengemukakan hubungan antara kecerdasan spiritual dengan pekerjaan. Kecerdasan spiritual ternyata memberikan pengaruh pada tingkah laku seseorang dalam bekerja.

Keberhasilan suatu organisasi dipengaruhi oleh kinerja (job performance) sumber daya manusia, untuk itu setiap perusahaan akan berusaha untuk meningkatkan kinerja pegawai dalam mencapai tujuan organisasi yang telah ditetapkan. Kemampuan pemimpin dalam menggerakkan dan memberdayakan pegawainya akan memengaruhi kinerja.

Permasalahan mengenai kinerja merupakan permasalahan yang akan selalu dihadapi oleh pihak manajemen perusahaan, karena itu manajemen perlu mengetahui faktor-faktor yang memengaruhi kinerja karyawan. Teori manajemen secara umum menyebutkan bahwa salah satu faktor yang keberadaannya perlu diperhatikan oleh sebuah organisasi dalam upaya mengikuti perkembangan yang terjadi adalah faktor sumber daya manusia.

Teori manajemen merupakan sebuah kumpulan ide-ide yang ditetapkan aturan umum tentang bagaimana mengelola sebuah bisnis atau organisasi. Teori 
Rio Surya Wijaya Theda dan Made Sukartha. Pengaruh...

manajemen membahas bagaimana manajer dan supervisor berhubungan dengan organisasi mereka dalam pengetahuan tentang tujuan, pelaksanaan cara yang efektif untuk mendapatkan tujuan dicapai dan bagaimana memotivasi karyawan untuk melakukan dengan standar tertinggi.

Kecerdasan intelektual, kecerdasan emosional, dan kecerdasan spiritual adalah suatu konsep yang mengacu pada teori sikap dan perilaku (Theory of Attitude and Behavior). Teori sikap dan perilaku menyatakan bahwa perilaku seseorang ditentukan oleh sikap yang terkait dengan apa yang orang-orang ingin lakukan, apa yang mereka pikirkan akan mereka lakukan (aturan-aturan sosial), dan apa yang mereka biasa lakukan (kebiasaan).

Pengertian sikap secara umum adalah suatu pikiran, kecenderungan dan perasaan seseorang untuk mengenal aspek-aspek tertentu pada lingkungan yang seringnya bersifat permanen karena sikap dari seseorang susah untuk diubah. Perilaku tidak mungkin terjadi jika situasinya tidak memungkinkan. Jika dikaitkan dengan penelitian ini teori sikap dan perilaku mampu memengaruhi pemilik UMKM untuk mengelola usahanya sehingga mampu berpikir rasional, bertindak jujur, tidak memihak pada suatu kepentingan tertentu yang nantinya akan memengaruhi kinerja UMKM.

Penelitian yang dilakukan Isabella (2011) dan Choiriah (2013), menemukan bahwa terdapat hubungan antara kecerdasan intelektual, kecerdasan emosional, dan kecerdasan spiritual terhadap kinerja auditor. Kinerja auditor yang baik akan meningkatkan kualitas audit yang baik pula. Penelitian yang dilakukan 
oleh Choiriah (2013), Apriyanti (2014) menyatakan bahwa kecerdasan emosional, kecerdasan spiritual berpengaruh positif terhadap kinerja auditor.

Penelitian yang dilakukan oleh Wijayanti (2012), menyatakan bahwa kecerdasan emosional akan mempermudah seorang auditor dalam melakukan pemeriksaan, memiliki motivasi yang kuat, mengontrol diri atau emosi, rasa empati, serta keterampilan dalam bersosialisasi yang akan membantu auditor dalam menelusuri bukti-bukti audit serta informasi terkait.

Berdasarkan paparan di atas, kecerdasan intelektual, kecerdasan emosional, dan kecerdasan spiritual memiliki sebuah keunggulan untuk memperoleh laba dalam sektor usaha mikro kecil menengah. Karena ketiga kecerdasan tersebut akan mempermudah kinerja dari seorang pemilik UMKM. Berdasarkan uraian latar belakang yang telah disampaikan, maka peneliti tertarik meneliti mengenai "Pengaruh Kecerdasan Intelektual, Kecerdasan Emosional, dan Kecerdasan Spiritual Pemilik Pada Kinerja UMKM di Kota Denpasar”.

Rumusan masalah pada penelitian ini adalah bagaimana pengaruh kecerdasan intelektual pemilik pada kinerja UMKM, bagaimana pengaruh kecerdasan spiritual pemilik pada kinerja UMKM, bagaimana pengaruh kecerdasan emosional pemilik pada kinerja UMKM.

Tujuan penelitian ini adalah untuk memberikan bukti empiris mengenai pengaruh kecerdasan intelektual pemilik pada kinerja UMKM, untuk memberikan bukti empiris mengenai pengaruh kecerdasan emosional pemilik pada kinerja UMKM, untuk memberikan bukti empiris mengenai pengaruh kecerdasan spiritual pemilik pada kinerja UMKM. 
Rio Surya Wijaya Theda dan Made Sukartha. Pengaruh...

Teori dasar pada penelitian ini adalah teori sikap dan perilaku. Teori sikap dan perilaku merupakan komponen pengetahuan yang selama ini diperoleh, di mana sangat memengaruhi perilaku dari seseorang tersebut saat bertindak. Sikap yang dimiliki setiap individu memberikan warna tersendiri untuk seseorang bertingkah laku. Teori sikap dan perilaku mampu memengaruhi dari kinerja UMKM tersebut. Kinerja berasal dari kata prestasi kerja (performance), sebagaimana dikemukakan oleh Mangkunegara (2006) bahwa istilah kinerja dari kata kata job performance atau actual performance (prestasi kerja atau prestasi sesungguhnya yang dicapai oleh seseorang) yaitu hasil kerja secara kualitas dan kuantitas yang dicapai oleh seorang pegawai dalam melaksanakan tugasnya sesuai dengan tanggung jawab yang diberikan padanya. Keberhasilan suatu organisasi dipengaruhi oleh kinerja (job performance) sumber daya manusia, untuk itu setiap perusahaan akan berusaha untuk meningkatkan kinerja pegawai dalam mencapai tujuan organisasi yang telah ditetapkan. Berdasarkan penelitian-penelitian terdahulu dan didukung oleh teori-teori diatas, maka hipotesis dari penelitian ini adalah :

$\mathrm{H}_{1}$ : Kecerdasan Intelektual berpengaruh positif pada kinerja UMKM.

$\mathrm{H}_{2}$ : Kecerdasan Emosional berpengaruh positif pada kinerja UMKM.

$\mathrm{H}_{3}$ : Kecerdasan Spiritual berpengaruh positif pada kinerja UMKM.

\section{METODE PENELITIAN}

Populasi dalam penelitian ini adalah semua pengusaha UMKM di kota Denpasar yang berjumlah 31.826 UMKM (ukmdenpasarkota.info, 2017).Teknik penentuan sampel yang digunakan dalam penelitian ini adalah Probably sampling digunakan 
dengan menggunakan teknik random sederhana, yaitu proses pengambilan sampel dilakukan dengan memberi kesempatan yang sama pada setiap anggota populasi untuk menjadi anggota sampel. Teori Slovin (dalam Umar 2003:108) menjelaskan rumus dalam perhitungan jumlah sampel dari keseluruhan populasi sebagai berikut:

$$
\mathrm{n}=\quad \frac{\mathrm{N}}{1+\mathrm{N}(\mathrm{e})^{2}}
$$

Keterangan:

$\mathrm{n}=$ ukuran sampel

$\mathrm{N}=$ ukuran populasi

$\mathrm{e}=$ ukuran ketelitian $(10 \%)$

Sehingga:

$$
\begin{aligned}
& \mathrm{n}=\frac{31.826}{1+31.826(0,1)^{2}} \\
& \mathrm{n}=\underline{31.826}
\end{aligned}
$$

319,26

$\mathrm{n}=99,686$

Berdasarkan perhitungan diatas, maka dapat ditetapkan besarnya minimal sampel dari populasi yaitu 100 UMKM (dibulatkan).

Variabel bebas dalam penelitian ini adalah kecerdasan intelektual pemilik $\left(\mathrm{X}_{1}\right)$, kecerdasan emosional pemilik $\left(\mathrm{X}_{2}\right)$, kecerdasan spiritual pemilik $\left(\mathrm{X}_{3}\right)$. Variabel terikat dalam penelitian ini adalah kinerja UMKM (Y). Metode pengumpulan data yang digunakan dalam penelitian ini adalah menggunakan metode survey, yaitu metode pengumpulan data primer dengan pertanyaan lisan 
Rio Surya Wijaya Theda dan Made Sukartha. Pengaruh...

atau tertulis. Teknik yang dipilih dari metode survey adalah dengan menggunakan kuesioner.

Analisis regresi linier berganda (multiple linear regression) digunakan untuk menguji hipotesis yang ada, yaitu untuk melihat pengaruh variabel kecerdasan intelektual, kecerdasan emosional, kecerdasan spiritual.

Model regresi dalam penelitian ini dinyatakan sebagai berikut.

$$
Y=a+b_{1} X_{1}+b_{2} X_{2}+b_{3} X_{3}+e
$$

\section{HASIL DAN PEMBAHASAN}

Pada penelitian ini jumlah responden yang digunakan adalah 100 sehingga derajat bebas pada tabel $\mathrm{r}$ adalah 98 . Nilai r-tabel untuk derajat bebas 98 adalah sebesar 0.1966. Nilai r-hitung item yang lebih besar dari 0.1966 dinyatakan valid.

Menunjukkan bahwa setiap item pernyataan dari masing-masing variabel pada kuesioner memiliki nilai $r$-hitung yang lebih besar dari pada $r$ tabel sebesar 0,196 sehingga 71 pernyataan dalam kuisioner yang digunakan dinyatakan valid. Selanjutnya uji yang dilakukan adalah uji reliabilitas. Reliabilitas instrumen penelitian dalam penelitian ini diuji dengan menggunakan koefisien Cronbach's Alpha. Suatu variabel dikatakan reliabel jika nilai Cronbach's Alpha $>0,60$.

Tabel 1.

Hasil Uji Reliabilitas

\begin{tabular}{lllll}
\hline No. & Variabel Penelitian & $\begin{array}{l}\text { Cronbach's } \\
\text { Apha }\end{array}$ & $\begin{array}{l}\text { Nilai } \\
\text { Minimum } \\
\text { Cronbach's } \\
\text { Apha }\end{array}$ & Keterangan \\
\hline 1 & Kinerja umkm & 0,915 & 0,600 & Reliabel \\
2 & Kecerdasan intelektual & 0,862 & 0,600 & Reliabel \\
3 & Kecerdasan emosional & 0,895 & 0,600 & Reliabel \\
4 & Kecerdasan spiritual & 0,911 & 0,600 & Reliabel \\
\hline
\end{tabular}

Sumber: Data diolah, 2018 
Uji reliabilitas pada Tabel menyajikan nilai Cronbach's Alpha masingmasing variabel pada kuisioner. Nilai Cronbach's Alpha yang dihasilkan lebih besar dari 0,6 dan cukup mendekati 1 sehingga dapat disimpulkan bahwa kuisioner yang digunakan sudah reliabel. Karena kuisioner sudah dinyatakan valid dan reliabel, maka kuisioner dapat digunakan sebagai alat ukur dan analisia lebih lanjut.

Statistik deskriptif digunakan untuk memberikan gambaran dari suatu data yang dilihat dari jumlah sampel, nilai minimum, nilai maksimum, nilai rata-rata (mean), dan standar deviasi dari masing-masing variabel di dalam penelitian. Berdasarkan data olahan SPSS yang meliputi variabel kecerdasan intelektual, kecerdasan emosional, kecerdasan spiritual dan kinerja UMKM, maka hasil analisis data untuk statistik deskriptif adalah sebagai berikut

Tabel 2.

Statistik Deskriptif

\begin{tabular}{llllll}
\hline & N & Minimum & Maximum & Mean & Std. Deviation \\
\hline Kinerja & 100 & 63.00 & 99.00 & 78.3500 & 8.13196 \\
Kecerdasan Intelektual & 100 & 30.00 & 50.00 & 38.7000 & 4.40500 \\
Kecerdasan Emosional & 100 & 71.00 & 111.00 & 89.5600 & 8.39110 \\
Kecerdasan Spiritual & 100 & 55.00 & 89.00 & 70.4300 & 7.41314 \\
Valid N (listwise) & 100 & & & & \\
\hline
\end{tabular}

Sumber : Data diolah, 2018

Menurut Ghozali (2013:160), uji normalitas bertujuan untuk menguji apakah dalam model regresi, variabel pengganggu atau residual memiliki distribusi normal. Dalam pengujian ini, uji normalitas yang digunakan yaitu uji statistik non-parametrik Kolmogrov-Smirnov. Adapun dasar uji K-S adalah:Angka signifikansi (sig) $>0,05$, maka data berdistribusi normal dan angka signifikansi (sig) $<0,05$, maka data tidak berdistribusi normal. 
Tabel 3.

Uji Normalitas

\begin{tabular}{ll}
\hline & Unstandardized Residual \\
\hline $\mathrm{N}$ & 100 \\
Kolmogorov-Smirnov Z & 0,678 \\
Asymp. Sig. (2-tailed) & 0,747 \\
\hline
\end{tabular}

Sumber: Data diolah, 2018

Hasil uji Kolmogorov-Smirnov menunjukkan bahwa nilai Asymp. Sig. (2tailed) sebesar 0,747. Nilai ini lebih besar dari signifikan 0,05 sehingga dapat disimpulkan bahwa data mengikuti sebaran normal. Oleh karena itu asumsi normalitas pada regresi telah terpenuhi.

Menurut Ghozali (2012:139), uji heteroskedastisitas bertujuan menguji apakah model regresi terjadi ketidaksamaan variance dari residual satu pengamatan ke pengamatan yang lain. Jika signifikan $t$ dari hasil meregresi nilai absolute residual terhadap variabel bebas lebih dari 0,05 maka model regresi tidak mengandung hoteroskedastisitas.

Tabel 4.

Hasil Uji Heterokedasitas

\begin{tabular}{lll}
\hline Model & T & Sig. \\
\hline Kecerdasan Intelektual & 0,255 & 0,799 \\
Kecerdasan Emosional & 1,130 & 0,261 \\
Kecerdasan Spiritual & $-0,283$ & 0,778 \\
\hline Sumber: Data diolah, 2018 & &
\end{tabular}

Jika model tersebut diuji secara parsial maka Tabel diatas menunjukkan bahwa semua variabel bebas yang digunakan pada penelitian memiliki nilai lebih besar dari 0,05 sehingga dapat disimpulkan bahwa tidak terjadi heterokedasitas.

Uji multikolonieritas bertujuan untuk menguji apakah dalam model regresi ditemukan adanya korelasi antar variabel bebas (independen). Menurut Ghozali (2013:105), model regresi yang baik seharusnya tidak terjadi korelasi diantara variabel independen. Jika variabel independen memiliki nilai tolerance lebih besar 
dari 10\% dan memiliki nilai Variance Inflation Factor (VIF) kurang dari 10, maka model regresi tersebut bebas dari masalah multikolinieritas.

Tabel 5.

Hasil Uji Multikolinearitas

\begin{tabular}{lll}
\hline Model & Tolerance & VIF \\
\hline Kecerdasan Intelektual & 0,997 & 1,003 \\
Kecerdasan Emosional & 0,996 & 1,004 \\
Kecerdasan Spiritual & 0,995 & 1,005 \\
\hline
\end{tabular}

Sumber: Data diolah, 2018

Tabel diatas menunjukkan bahwa untuk semua variabel independen yang digunakan memiliki nilai VIF yang dihasilkan kurang dari 10 dan nilai tolerance $>10 \%$ sehingga dapat disimpulkan bahwa tidak terjadi korelasi ganda (multikolinieritas) antar variabel independen.

Koefisien Determinasi $\left(\mathrm{R}^{2}\right)$ bertujuan untuk mengetahui seberapa besar variabel independen mampu menjelaskan dan mempengaruhi variabel dependen. Nilai koefisien determinasi adalah antara nol dan satu. Nilai yang mendekati satu berarti variabel-variabel indepenen memberikan hampir semua informasi yang dibutuhkan untuk memprediksi variasi variabel dependen (Ghozali : 2009).

Persamaan yang di gunakan adalah sebagai berikut :

$$
\mathrm{D}=\mathrm{R}^{2} \mathrm{X} 100 \% \text { atau } \mathrm{D}=\operatorname{Adjs} \mathrm{R}^{2} \mathrm{X} 100 \%
$$

Tabel 6.

Hasil Uji Koefisien Determinasi

\begin{tabular}{lllll}
\hline Model & R & R Square & $\begin{array}{l}\text { Adjusted } \\
\text { Square }\end{array}$ & $\begin{array}{l}\text { Std. Error of the } \\
\text { Estimate }\end{array}$ \\
\hline 1 & 0,921 & 0,848 & 0,843 & 0,17160 \\
\hline Sumber: Data diolah, 2018 & & &
\end{tabular}

Analisis regresi yang digunakan adalah analisis regresi berganda sehingga koefisien determinasi yang digunakan adalah Adjusted $\mathrm{R}$ square (koefisien determinasi terkoreksi). Nilai koefisien yang diperoleh adalah sebesar 0,843. Nilai 
Rio Surya Wijaya Theda dan Made Sukartha. Pengaruh...

determinasinya menjadi $0,843 \times 100 \%=84,3 \%$. Hal ini mengindikasikan bahwa Kinerja UMKM dijelaskan $84,3 \%$ oleh Variabel Kecerdasan Intelektual, Kecerdasan Emosional dan Kecerdasan Spiritual sisanya dijelaskan oleh variabel lain yang tidak dimasukkan ke dalam model.

Uji statistik F bertujuan untuk mengetahui kelayakan model regresi linier berganda sebagai alat analisis yang menguji pengaruh variable independen terhadap variable dependen. Pengujian dilakukan dengan menggunakan significance level 0,05 $(\alpha=5 \%)$. Ketentuan penerimaan atau penolakan hipotesis adalah sebagai berikut : jika nilai signifikansi $>0,05$ maka $\mathrm{H}_{0}$ diterima (koefisien regresi tidak signifikansi), ini berarti bahwa secara silmutan variable independen tersebut tidak berpengaruh signifikan terhadap variable dependen. Jika nilai siginifikansi $\leq$ 0,05 maka $\mathrm{H}_{0}$ ditolak (koefisien regresi signifikansi), ini berarti secara silmutan variabel independen tersebut berpengaruh signifikansi terhadap variabel dependen.

Tabel 7.

Hasil Uji Kelayakan Model (Uji F)

\begin{tabular}{|c|c|c|c|c|c|}
\hline Model & $\begin{array}{l}\text { Sum o } \\
\text { Squares }\end{array}$ & df & $\begin{array}{l}\text { Mean } \\
\text { Square }\end{array}$ & $\mathbf{F}$ & Sig. \\
\hline Regression & 15,710 & 3 & 5,237 & 177,840 & 0,000 \\
\hline Residual & 2,827 & 96 & 0,029 & & \\
\hline Total & 18,537 & 99 & & & \\
\hline
\end{tabular}

Sumber: Data diolah, 2018

Pada Tabel tersebut dapat dilihat nilai signifikansi sebesar 0,000 atau < 0,05 maka menunjukkan bahwa variabel independen yang digunakan yaitu kecerdasan intelektual, kecerdasan emosional, dan kecerdasan spiritual yang dipersepsikan berpengaruh secara simultan. 
Uji t digunakan untuk menguji apakah masing-masing variable independen berpengaruh pada variabel dependen. Pengujian ini dapat dilakukan dengan melihat pada hasil regresi yang dilakukan dengan program SPSS, yaitu dengan membandingkan tingkat signifikansi masing-masing variabel bebas 0,05 ( $\alpha=$ 5\%). Ketentuan penerimaan atau penolakan hipotesis adalah sebagai berikut: bila probabilitas signifikansi dari $\mathrm{t}>\alpha$, maka $\mathrm{H}_{0}$ diterima dan $\mathrm{H}_{1}$ ditolak, hal ini berarti secara individual variabel independen tidak memiliki pengaruh pada variabel dependen. Bila probabilitas signifikansi dari $\mathrm{t} \leq \alpha$, maka $\mathrm{H}_{0}$ ditolak dan $\mathrm{H}_{1}$ diterima, hal ini berarti secara individual variabel independen memiliki pengaruh pada variabel dependen.

Tabel 8.

Hasil Uji Hipotesis (Uji t)

\begin{tabular}{|c|c|c|c|c|c|}
\hline \multirow[t]{2}{*}{ Model } & \multicolumn{2}{|c|}{$\begin{array}{l}\text { Unstandardized } \\
\text { Coefficients }\end{array}$} & \multirow{2}{*}{$\begin{array}{l}\text { Standardized } \\
\text { Coefficients } \\
\text { Beta }\end{array}$} & \multirow[t]{2}{*}{$\mathbf{T}$} & \multirow[t]{2}{*}{ Sig. } \\
\hline & B & Std. Error & & & \\
\hline (Constant) & 83,793 & 13,832 & & 6,058 & 0,000 \\
\hline $\begin{array}{l}\text { Kecerdasan } \\
\text { Intelektual }\end{array}$ & 0,374 & 0,141 & 0,416 & 2,660 & 0,011 \\
\hline $\begin{array}{l}\text { Kecerdasan } \\
\text { Emosional }\end{array}$ & 0,220 & 0,160 & 0,215 & 2,375 & 0,016 \\
\hline $\begin{array}{l}\text { Kecerdasan } \\
\text { Spiritual }\end{array}$ & 0,266 & 0,066 & 0,270 & 4,013 & 0,000 \\
\hline
\end{tabular}

Adapun hal-hal yang dapat diinterpretasikan dari tabel tersebut adalah sebagai berikut:

Variabel Kecerdasan Intelektual, setelah diuji secara parsial dengan menggunakan uji t, diperoleh nilai signifikansi sebesar 0,011. Nilai signifikansi ini lebih kecil dari 0,05 sehingga dapat disimpulkan bahwa variabel Kecerdasan Intelektual memiliki pengaruh pada Kinerja UMKM. Nilai koefisien bertanda positif sehingga disimpulkan variabel kecerdasan intelektual berpengaruh positif 
Rio Surya Wijaya Theda dan Made Sukartha. Pengaruh...

pada kinerja UMKM. Dengan demikian hipotesis pertama yang berbunyi Kecerdasan Intelektual berpengaruh positif pada kinerja UMKM diterima.

Variabel Kecerdasan Emosional, setelah diuji secara parsial dengan menggunakan uji t, diperoleh nilai signifikansi sebesar 0,016. Nilai signifikansi ini lebih kecil dari 0,05 sehingga dapat disimpulkan bahwa variabel Kecerdasan Emosional memiliki pengaruh pada Kinerja UMKM. Nilai koefisien bertanda positif sehingga disimpulkan variabel kecerdasan emosional berpengaruh positif pada kinerja UMKM. Dengan demikian hipotesis kedua yang berbunyi Kecerdasan Emosional berpengaruh positif pada kinerja UMKM diterima.

Variabel Kecerdasan Spiritual, setelah diuji secara parsial dengan menggunakan uji t, diperoleh nilai signifikansi sebesar 0,000. Nilai signifikansi ini lebih kecil dari 0,05 sehingga dapat disimpulkan bahwa variabel Kecerdasan Spiritual memiliki pengaruh pada Kinerja UMKM. Nilai koefisien bertanda positif sehingga disimpulkan variabel kecerdasan spiritual berpengaruh positif pada kinerja UMKM. Dengan demikian hipotesis ketiga yang berbunyi Kecerdasan Spiritual berpengaruh positif pada kinerja UMKM diterima.

$$
\mathrm{Y}=83,793+0,374 \mathrm{X} 1+0,220 \mathrm{X} 2+0,266 \mathrm{X} 3+\mathrm{e}
$$

Model ini memiliki interpretasi sebagai berikut: Constanta senilai 83,793 berarti bahwa ketika kecerdasan intelektual, kecerdasan emosional, dan kecerdasan spiritual pemilik UMKM sangat rendah, kinerja UMKM senilai 83,793 satuan. Nilai koefisien Variabel Kecerdasan Intelektual bernilai positif sebesar 0,374 maka artinya apabila nilai Kecerdasan Intelektual naik satu satuan maka Kinerja UMKM akan naik sebesar 0,374, apabila nilai Variabel Kecerdasan 
Emosional dan Kecerdasan Spiritual dipertahankan konstan. Nilai koefisien Variabel Kecerdasan Emosional bernilai positif sebesar 0,220 maka artinya apabila nilai Kecerdasan Emosional naik satu satuan maka Kinerja UMKM akan naik sebesar 0,220, apabila nilai variabel Kecerdasan Intelektual dan Kecerdasan Spiritual dipertahankan konstan. Nilai koefisien Variabel Kecerdasan Spiritual bernilai positif sebesar 0,266 maka artinya apabila nilai Kecerdasan Spiritual naik satu satuan maka Kinerja UMKM akan naik sebesar 0,266, apabila nilai Variabel Kecerdasan Intelektual, Kecerdasan Emosional dipertahankan konstan.

Kecerdasan intelektual memiliki nilai koefisien regresi sebesar 0,374 dengan nilai signifikansi sebesar $0,011<\alpha(0,05)$ yang berarti bahwa variabel kecerdasan intelektual memiliki pengaruh positif pada kinerja UMKM. Pada penelitian ini dapat dijustifikasi bahwa kecerdasan inteletual berpengaruh positif pada kinerja sejalan dengan teori sikap dan perilaku yang menyatakan kecerdasan intelektual berpengaruh pada kinerja UMKM. Dimana semakin baik kecerdasan intelektual, maka kinerja tersebut makin baik. Hasil penelitian ini sejalan dengan hasil penelitian yang dilakukan oleh Isabella (2011) dan Choiriah (2013) yang mengungkapkan bahwa kecerdasan intelektual berpanguruh poisitif pada kinerja.

Kecerdasan emosional memiliki nilai koefisien regresi sebesar 0,220 dengan nilai signifikansi sebesar $0,016<\alpha(0,05)$ yang berarti bahwa variabel Kecerdasan Emosional memiliki pengaruh positif pada Kinerja UMKM. Pada penelitian ini dapat dijustifikasi bahwa kecerdasan emosional berpengaruh positif pada kinerja sejalan dengan teori sikap dan perilaku yang menyatakan kecerdasan emosional berpengaruh pada kinerja UMKM. Dimana semakin baik kecerdasan 
Rio Surya Wijaya Theda dan Made Sukartha. Pengaruh...

emosional, maka kinerja tersebut makin baik. Hasil penelitian ini sejalan dengan hasil penelitian yang dilakukan oleh Wijayanti (2012), Choiriah (2013) dan Apriyanti (2014) yang mengungkapkan bahwa kecerdasan emosional berpengaruh positif pada kinerja.

Kecerdasan spiritual memiliki nilai koefisien regresi sebesar 0,266 dengan nilai signifikansi sebesar $0,000<\alpha(0,05)$ yang berarti bahwa variabel Kecerdasan Spiritual memiliki pengaruh positif pada Kinerja UMKM. Pada penelitian ini dapat dijustifikasi bahwa kecerdasan spiritual berpengaruh positif pada kinerja sejalan dengan teori sikap dan perilaku yang menyatakan kecerdasan spiritual berpengaruh pada kinerja UMKM. Dimana semakin baik kecerdasan spiritual maka kinerja makin baik. Hasil penelitian ini sejalan dengan hasil penelitian yang dilakukan oleh Choiriah (2013) dan Apriyanti (2014) yang mengungkapkan bahwa kecerdasan spiritual berpengaruh positif pada kinerja.

Hasil penelitian ini mendukung hasil penelitian dari Isabella (2011), Wijayanti (2012), Choiriah (2013), Apriyanti (2014) yang menytakan bahwa kecerdasan intelektual, kecerdasan emosional, dan kecerdasan spiritual berpengaruh terhadap kinerja usaha mikro kecil menengah di kota Denpasar.

Berdasarkan hasil pengujian yang telah dilakukan, penelitian ini memberikan implikasi teoritis bahwa teori sikap dan perilaku (Theory of Attitude and Behavior) dapat menjelaskan pengaruh kecerdasan intelektual, kecerdasan emosional, dan kecerdasan spiritual pemilik pada kinerja Usaha Mikro Kecil Menegah di Kota Denpasar. Hasil uji dalam penelitian ini menemukan bahwa kecerdasan intelektual, kecerdasan emosional, dan kecerdasan spiritual 
berpengaruh positif pada kinerja UMKM. Oleh karenanya pengembangan UMKM di Kota Denpasar sebaiknya didasarkan pada ketiga kecerdasan, yaitu kecerdasan intelektual, kecerdasan emosional, dan kecerdasan spiritual.

Penelitian ini dapat memberikan informasi bagi pemilik UMKM sebagai bahan referensi untuk selanjutnya menerapkan kecerdasan intelektual, kecerdasan emosional, dan kecerdasan spiritual pada Usaha Mikro Kecil Menengah guna meningkatkan kinerja UMKM. Penelitian ini juga dapat memberikan informasi bagi pihak-pihak yang berkepentingan sebagai bahan referensi untuk melakukan penelitian-penelitian selanjutnya.

\section{SIMPULAN}

Berdasarkan hasil analisis dan pembahasan mengenai bagaimana Pengaruh Kecerdasan Intelektual, Kecerdasan Emosional, dan Kecerdasan Spiritual Pemilik Pada Kinerja UMKM di Kota Denpasar maka dapat ditarik kesimpulan sebagai berikut: Kecerdasan intelektual pemilik memiliki pengaruh positif signifikan pada kinerja UMKM, yang artinya jika kecerdasan intelektual pemilik mengalami peningkatan maka kinerja UMKM juga akan mengalami peningkatan secara signifikan.Kecerdasan emosional pemilik memiliki pengaruh positif signifikan pada kinerja UMKM, yang artinya jika kecerdasan emosional pemilik mengalami peningkatan maka kinerja UMKM juga akan mengalami peningkatan secara signifikan. Kecerdasan spiritual pemilik memiliki pengaruh positif signifikan pada kinerja UMKM, yang artinya jika kecerdasan spiritual pemilik mengalami peningkatan maka kinerja UMKM juga akan mengalami peningkatan secara signifikan. 
Rio Surya Wijaya Theda dan Made Sukartha. Pengaruh...

Adapun saran yang dapat diberikan untuk pengembangan penelitian selanjutnya adalah. Penelitian selanjutnya diharapkan dapat memperluas lokasi penelitian yang ada di Bali, sehingga hasil pengujian mengenai kinerja UMKM lebih menyeluruh dan dapat memperluas penelitian sebelumnya, serta Penelitian selanjutnya dapat menambahkan jumlah populasi atau sampel yang dijadikan pengamatan dalam penelitian ini.

\section{REFRENSI}

Apriyanti. 2014. Pengaruh Kecerdasan Emosional, Kecerdasan Spiritual dan Perilaku Etis terhadap Kinerja Auditor Pemerintah. JOM FEKON. Vol 1.

Biberma, J, and Whittey, M. 1997. A Postmodern Spiritual Future For Work.Journal of Organizational Change Management, 10 (2), pp.30-188

Boyatzis, R,E, Ron, S. 2001. Unleashing the Power of Self Directed Learning. Case Western Reserve University, Cleveland, Ohio, USA

Chermiss, C. 1998. Working With Emotional Intelligence. The Consortium For Research On Emotional Intelligence in Organizations. Rugrets University,New Jersey

Choiriah, Anis. 2013. Pengaruh Kecerdasan Emosional. Kecerdasan Intelektual, Kecerdasan Spiritual, dan Etika Profesi Terhadap Kinerja Auditor dalam Kantor Akuntan Publik (Studi Empiris pada Auditor dalam Kantor Akuntan Publik di Kota Padang dan Pekanbaru). Jurnal Universitas Negeri Padang, Padang

Floretta, Gabritha. 2014. Pengaruh Kecerdasan Emosional, Kecerdasan Spiritual dan Etika Profesi terhadap Kinerja Auditor pada Kantor Akuntan Publik DKI Jakarta. Jurnal Binus University. Jakarta Barat.

Ghozali, Imam. 2009. Aplikasi Analisis Multivariate dengan Program SPSS, Edisi 4, Badan Penerbit Universitas Diponegoro, Semarang.

Ghozali, Imam. 2012. Aplikasi Analisis Multivariate dengan Program IBM SPSS 20. Semarang: Badan Penerbit - Universitas Diponegoro.

Ghozali, Imam. 2013. Aplikasi Analisis Multivariate dengan Program SPSS. Badan Penerbit Universitas Diponegoro, Semarang. 
Goleman, Daniel. 1999. Kecerdasan Emosional. Terjemahan, Cetakan IX. Jakarta: Gramedia Pustaka Utama.

Goleman. 2006. Emotional Intelligence: Kecerdasan Emosi, Mengapa El Lebih Penting daripada IQ. Ahli Bahasa: T.Hermaya. Cetakan Keenam Belas. Jakarta: PT Gramedia Pustaka Utama.

Hoffman, E. 2002. Psychological testing at work. New York: McGraw-Hill.

Isabella. 2011. Pengaruh Kecerdasan Emosional, Kecerdasan Spiritual Dan Kecerdasan Intelektual Terhadap Kinerja Auditor Dalam Kantor Akuntan Publik. Skripsi Sarjana pada Jurusan Ajuntansi Fakultas Ekonomi Universitas Katolik Soegijapranata Semarang

Mangkunegara, A. P. 2006. Evaluasi Kinerja Sumber Daya Manusia. Bandung: PT. Repika Utama.

Mathis dan Jackson. 2002. Manajemen sumber daya manusia, Salemba Empat; Jakarta

Mitroff, L.I and Denton, E.A. 1999. A Study of Spiritualty in The Work Place, Sloan Management Review, 40 (4), pp.83-92

Robbins, Stephen P. Dan Timothy A. Judge. 2008. Perilaku Organisasi Edisi ke12. Jakarta: Salemba Empat

Trihandini, Fabiola Meirnayati. 2005. Analisis Pengaruh Kecerdasan Intelektual, Kecerdasan Emosi dan Kecerdasan Spiritual terhadap Kinerja Karyawan (Studi Kasus di Hotel Horison Semarang). Dalam Tesis Progam Magister Manajemen Pascasarjana Universitas Diponegoro.

Wijayanti, Gersontan Lewi. 2012. Peran Kecerdasan Emosional Dan Kecerdasan Spiritual Dalam Meningkatkan Kinerja Auditor. Dalam Jurnal Ilmiah Mahasiswa Akuntansi Vol 1, No.2 